Contract Program or Project Title:

Subject of this Document:

Type of Document:

Authors:

Date of Document:

Responsible NRC Individual and NRC Office or Division:
Heavy Section Steel Irradiation (HSSI) Program, Metals and Ceramics Division

Design, Fabrication, and Initial Operation of a Reusable Irradiation Facility

Letter Report

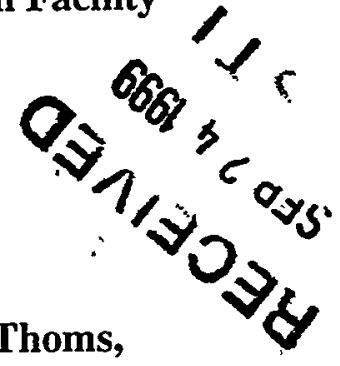

D. W. Heatherly, K. R. Thoms,

I. I. Siman-Tov, and M. T. Hurst

June 1999

Carolyn J. Fairbanks (301-415-6719)

Division of Engineering Technology

U.S. Nuclear Regulatory Commission

Prepared for the

U.S. Nuclear Regulatory Commission

Washington, DC 20555

Under Interagency Agreement DOE 1886-N695-3W

NRC JCN W6953

OAK RIDGE NATIONAL LABORATORY

Oak Ridge, TN 37832-6376

managed by

LOCKHEED MARTIN ENERGY RESEARCH CORPORATION

for the

U.S. Department of Energy

under Contract No. DE-AC05-96OR22464 
This report has been reproduced from the best available copy.

Reports are available to the public from the following source.

National Technical Information Service

5285 Port Royal Road

Springfield, VA 22161

Telephone 703-605-6000 (1-800-553-6847)

TDD 703-487-4639

Fax 703-605-6900

E-mail orders@ntis.fedworld.gov

Web site http://www.ntis.gov/ordering.htm

Reports are available to U.S. Department of Energy (DOE) employees, DOE contractors, Energy Technology Data Exchange (ETDE) representatives, and International Nuclear Information System (INIS) representatives from the following source.

Office of Scientific and Technical Information

P.O. Box 62

Oak Ridge, TN 37831

Telephone 423-576-8401

Fax 423-576-5728

E-mail reports@adonis.osti.gov

Web site http://www.osti.gov/products/sources.html

Reports produced after January 1, 1996, are generally available via the DOE Information Bridge. Web site http://www.doe.gov/bridge

This report was prepared as an account of work sponsored by an agency of the United States government. Neither the United States government nor any agency thereof, nor any of their employees, makes any warranty, express or implied, or assumes any legal liability or responsibility for the accuracy, completeness, or usefulness of any information, apparatus, product, or process disclosed, or represents that its use would not infringe privately owned rights. Reference herein to any specific commercial product, process, or service by trade name, trademark, manufacturer, or otherwise, does not necessarily constitute or imply its endorsement, recommendation, or favoring by the United States government or any agency thereof. The views and opinions of authors expressed herein do not necessarily state or reflect those of the United States government or any agency thereof. 


\section{DISCLAIMER}

Portions of this document may be illegible in electronic image products. Images are produced from the best available original document. 
Engineering Technology Division

\title{
DESIGN, FABRICATION, AND INITIAL OPERATION OF A REUSABLE IRRADIATION FACILITY
}

D. W. Heatherly, K. R. Thoms, I. I. Siman-Tov, and M. T. Hurst*

*Instrumentation and Controls Division.

Manuscript Completed-June 1999

Date Published-July 1999

\author{
Prepared for the \\ U.S. Nuclear Regulatory Commission \\ Washington, DC 20555 \\ Under Interagency Agreement DOE 1886-N695-3W \\ NRC JCN W6953. \\ . OAK RIDGE NATIONAL LABORATORY \\ Oak Ridge, TN 37832-6376 \\ managed by \\ LOCKHEED MARTIN ENERGY RESEARCH CORPORATION \\ for the \\ U.S. Department of Energy \\ under Contract No. DE-AC05-96OR22464
}




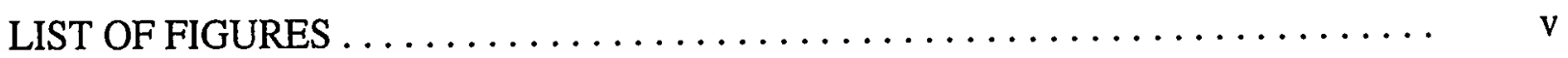

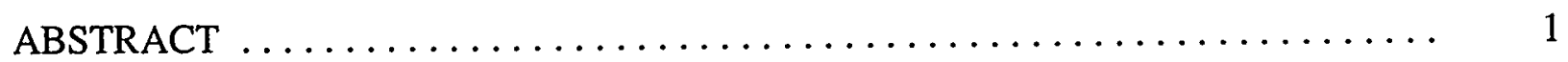

1. INTRODUCTION $\ldots \ldots \ldots \ldots \ldots \ldots \ldots \ldots \ldots \ldots \ldots \ldots \ldots \ldots \ldots \ldots \ldots \ldots \ldots$

2. HSSI-IAR FACILITY $\ldots \ldots \ldots \ldots \ldots \ldots \ldots \ldots \ldots \ldots \ldots \ldots \ldots \ldots \ldots \ldots \ldots \ldots$

3. HSSI-IAR IRRADIATION CAPSULE $\ldots \ldots \ldots \ldots \ldots \ldots \ldots \ldots \ldots \ldots \ldots \ldots \ldots$

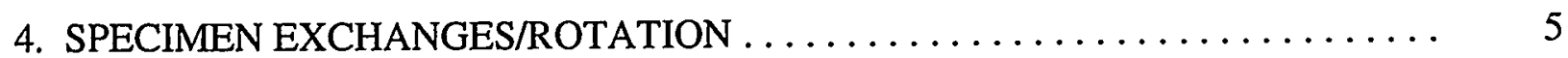

5. OPERATION OF THE HSSI-IAR FACILITIES $\ldots \ldots \ldots \ldots \ldots \ldots \ldots \ldots .7$

6. TEMPERATURE AND DOSIMETRY CHARACTERIZATION $\ldots \ldots \ldots \ldots \ldots$. 8

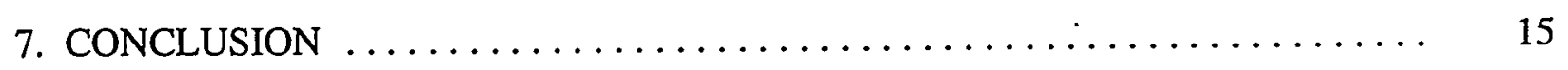

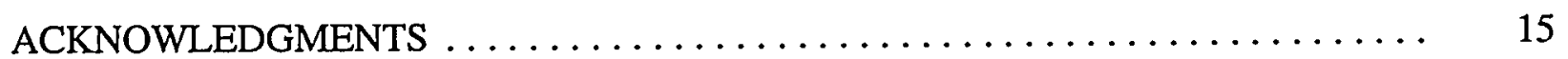




\section{LIST OF FIGURES}

Figure $\quad$ Page

$1 \quad$ East face irradiation facility at the FNR $\ldots \ldots \ldots \ldots \ldots \ldots \ldots \ldots, 2$

2. Cross section through an IAR facility and capsule at FNR core centerline ............................. 3

3 Schematic of HSSI-IAR irradiation capsule and facility

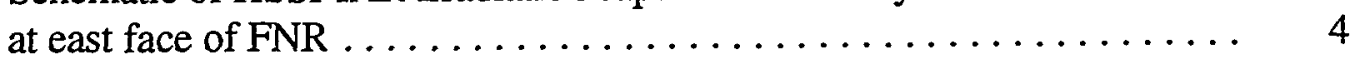

$4 \quad$ Shelf plate and thermocouple locations in the HSSI-IAR irradiation capsule $\ldots \ldots \ldots \ldots \ldots \ldots \ldots \ldots \ldots \ldots \ldots \ldots \ldots$

$5 \quad$ HSSI-IAR irradiation capsule and specimen container loaded with $151 \mathrm{~T}$ compact-tension specimens . . . . . . . . . . . . . . . . . . .

6 Thermocouple temperatures $\left({ }^{\circ} \mathrm{C}\right)$ for gamma heating only in the north facility $($ IAR-1 $) \ldots \ldots \ldots \ldots \ldots \ldots \ldots \ldots \ldots \ldots$

7 Thermocouple temperatures $\left({ }^{\circ} \mathrm{C}\right)$ for gamma heating only in the south facility (IAR-2) $\ldots \ldots \ldots \ldots \ldots \ldots \ldots \ldots \ldots \ldots$

8 Thermocouple temperatures $\left({ }^{\circ} \mathrm{C}\right)$ with $3910 \mathrm{~W}$ electrical heating in the north facility $($ IAR-1) $\ldots \ldots \ldots \ldots \ldots \ldots \ldots \ldots \ldots \ldots \ldots$

9 Thermocouple temperatures $\left({ }^{\circ} \mathrm{C}\right)$ with $5248 \mathrm{~W}$ electrical heating in the south facility (IAR-2) $\ldots \ldots \ldots \ldots \ldots \ldots \ldots \ldots \ldots \ldots$

10 IAR-1 and IAR-2 electrical heater power input before and after cranking against reactor $\ldots \ldots \ldots \ldots \ldots \ldots \ldots \ldots \ldots, 13$

11 Temperature/time plot for thermocouples 1-4 in IAR-1 during complete reactor half-cycle $\ldots \ldots \ldots \ldots \ldots \ldots \ldots \ldots \ldots \ldots .14$

12 Temperature/time plot for thermocouples $1-4$ for short period of time indicating excellent temperature control 


\title{
DESIGN, FABRICATION, AND INITIAL OPERATION OF A REUSABLE IRRADIATION FACILITY
}

\author{
D. W. Heatherly, K. R. Thoms, I. I. Siman-Tov, and M. T. Hurst
}

\begin{abstract}
A Heavy-Section Steel Irradiation (HSSI) Program project, funded by the U.S. Nuclear Regulatory Commission, was initiated at Oak Ridge National Laboratory to develop reusable materials irradiation facilities in which metallurgical specimens of reactor pressure vessel steels could be irradiated. As a consequence, two new, identical, reusable materials irradiation facilities have been designed, fabricated, installed, and are now operating at the Ford Nuclear Reactor at the University of Michigan. The facilities are referred to as the HSSI-IAR facilities with the individual facilities being designated as IAR-1 and IAR-2. This new and unique facility design requires no cutting or grinding operations to retrieve irradiated specimens, all capsule hardware is totally reusable, and materials transported from site to site are limited to specimens only. At the time of this letter report, the facilities have operated successfully for approximately 2500 effective full-power hours.
\end{abstract}

\section{INTRODUCTION}

Irradiation and testing of reactor-pressure-vessel (RPV) steels has been performed by Oak Ridge National Laboratory (ORNL) under the Heavy-Section Steel Irradiation Program (HSSI) for the U.S. Nuclear Regulatory Commission (NRC) for more than 20 years in order to determine the condition of currently-in-use RPVs and to investigate the possibility of plant-life extension. Typical irradiation experiments consisted of a sealed container that housed the metallurgical specimens to be irradiated. Specimen sizes varied considerably but usually were in the form of compacttension, Charpy, tensile, crack arrest, or drop-weight specimens. New specimens were sealed in the test vehicle with the heaters, thermocouples, and flux monitors, and the entire assembly was irradiated for the time necessary to provide desired fluence. The entire assembly was then shipped from the reactor site to a hot cell where the sealed test vehicle and all instrumentation leads were destroyed to recover the irradiated specimens for testing. Fabrication of additional test vehicles was required to irradiate additional specimens under the same conditions or to investigate the effects of differing conditions on similar materials.

All but the previous two irradiation experiments performed for the NRC by ORNL were irradiated in reactors at ORNL. Disassembly of the experiments also took place on site, which required that the irradiated experiment be shipped in a lead-shielded container for a short distance from the reactor facility to the hot-cell facility. Because of the shutdown of reactor facilities at ORNL, irradiations now must be performed at an off-site reactor. The HSSI Program has chosen the Ford Nuclear Reactor (FNR) at the University of Michigan to perform these irradiations. Because the FNR does not have a hot cell large enough for the operations required to disassemble the experiments and retrieve specimens, it would be necessary to ship all of these irradiated materials to the ORNL facilities. Shipment of irradiated materials over public highways has proved to be quite 
different from an ORNL on-site shipment and is a slow and expensive process. Because shipment, disassembly, and disposal of nonspecimen hardware proved to be more and more difficult and expensive, the facilities were designed such that everything could be reused. With such a facility it would only be necessary to ship specimens from FNR to ORNL.

As a consequence, two new identical materials irradiation facilities have been designed, fabricated, installed, and are now operating at the FNR at the University of Michigan. The facilities are referred to as the HSSI-IAR with the individual facilities being designated as IAR-1 and IAR-2. The design and fabrication of the facilities were completed in October 1998, and they were tested at ORNL in early November 1998. The completed facilities, irradiation capsules, specimen transfer cask, and instrumentation were delivered and installed at FNR in mid-November 1998. The facilities became operational, and the temperature and dosimetry characterization tests were performed from November 19, 1998, to December 11, 1998. On December 16, 1998, irradiation of the first metallurgical specimens began. At the time of this letter report, the facilities have operated successfully for approximately 2500 effective full-power hours (EFPHs).

The HSSI-IAR facilities are located on the east face of the FNR core. Between the IAR-1 and IAR-2 facilities is the HSSI-University of California, Santa Barbara (UCSB) Irradiation Facility (another HSSI project), which has been operating for approximately 10,000 EFPHs since December 1996. The IAR-1 facility is located on the north side of the UCSB facility, and the IAR-2 facility is located on the south side of the UCSB facility, as shown in Fig. 1. The three

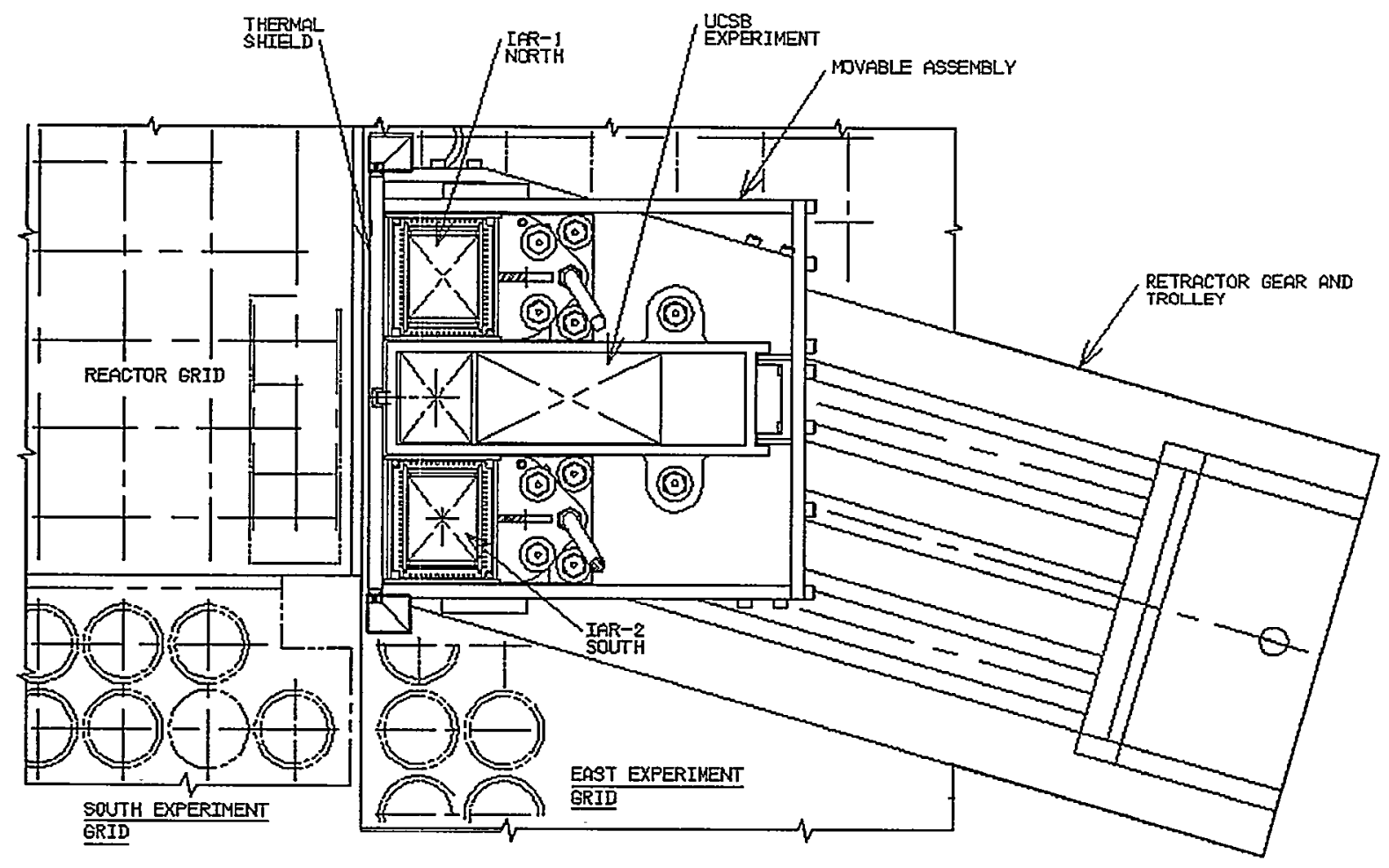

Figure 1. East face irradiation facility at the FNR. 
facilities are positioned inside a cagelike assembly constructed of aluminum, except for the front plate, which is 0.5 -in.-thick $(12.7-\mathrm{mm})$ stainless steel. This front plate, or thermal shield, provides gamma attenuation to reduce the gamma heating in the irradiation experiments. The cagelike assembly containing the three facilities is mounted on a movable carriage assembly, which is installed in the experiment grid on the east side of the FNR core. The carriage assembly is used to crank the three facilities, as a unit, into and away from the FNR core face.

\section{HSSI-IAR FACIITY}

An HSSI-IAR facility consists of a 9-ft-tall (2.7-m) container assembly fabricated from 304L stainless steel, inside of which is placed the irradiation capsule containing the metallurgical specimens. The lower 24-in. (0.6-m) portion of the facility, where the specimen loaded capsule resides, is rectangular in shape with external dimensions of 4.52 in. $(11.48 \mathrm{~cm})$ wide and $4.14 \mathrm{in}$. $(10.52 \mathrm{~cm})$ deep. The electrical heaters for the facility are located in this area. The facility has 12 separate heater zones with 3 heater zones (top, middle, and bottom) on each of the 4 sides of the facility. These heaters are used for heating the specimens inside the irradiation capsule to the desired irradiation temperature of $288^{\circ} \mathrm{C}\left(550^{\circ} \mathrm{F}\right)$, and if so desired, the same heaters can be used to heat treat the specimens up to $454^{\circ} \mathrm{C}\left(850^{\circ} \mathrm{F}\right)$. The heater zones are strategically placed such that varying the power from the separate heater zones can overcome the varying gamma heating rates in the capsule, resulting in all specimens being at the desired irradiation temperature of $288^{\circ} \mathrm{C}$. The facility is continuously swept with helium although it is possible to use mixtures of helium and neon if necessary to achieve desired temperatures. Figure 2 shows a cross-sectional view of an IAR facility and capsule at the FNR core midplane.

The upper 84-in. $(2.1-\mathrm{m})$ portion of the facility is cylindrical in shape and is $5 \mathrm{in} .(12.7 \mathrm{~cm})$ in diameter. It is open at the top and has a retaining yoke that is bolted to retain the irradiation

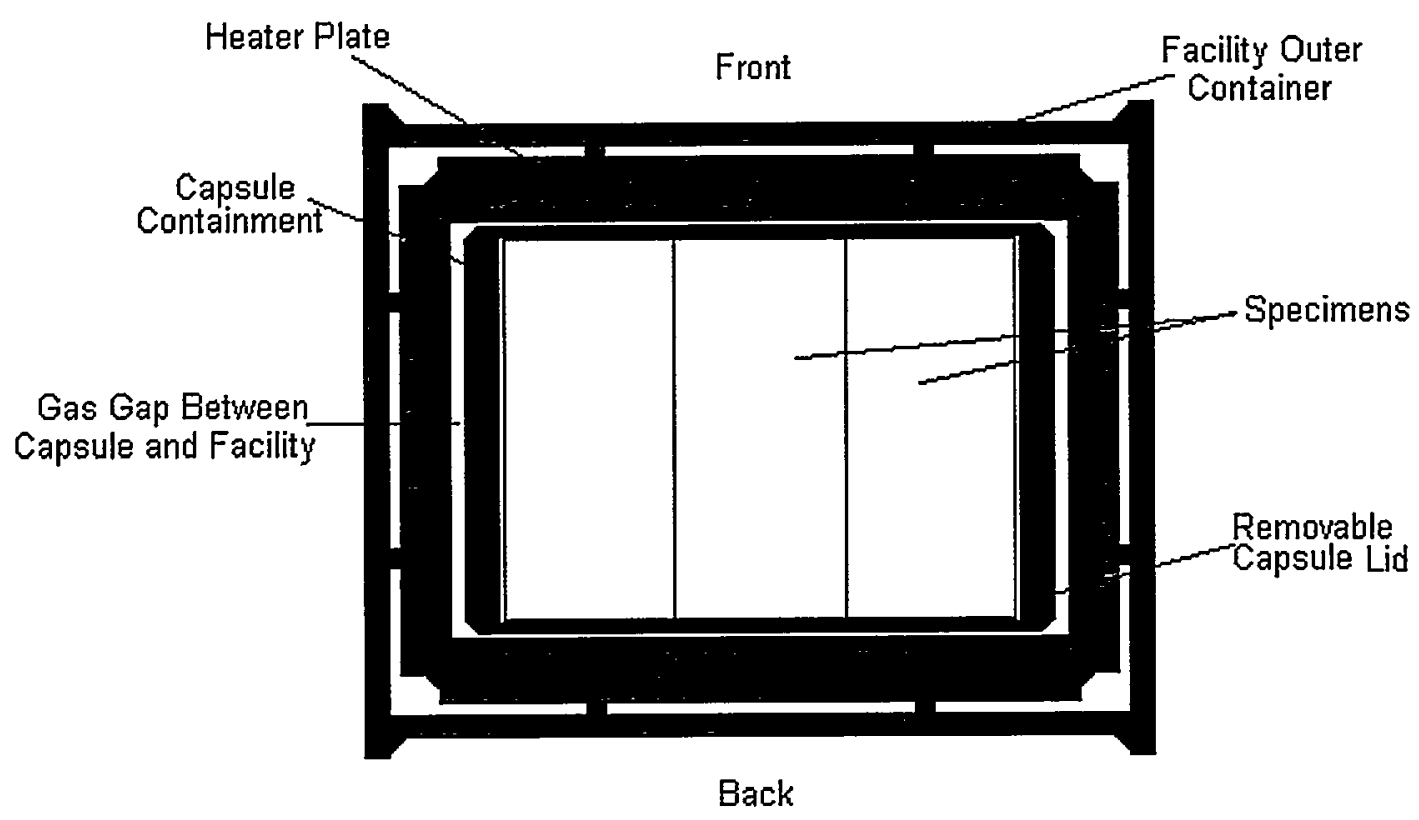

Figure 2. Cross section through an IAR facility and capsule at FNR core centerline. 
capsule inside the facility. When the capsule is installed, the opening in the top of the facility is sealed by an O-ring on the upper flange of the irradiation capsule inserted into the facility. These dimensions and geometry allow the capsule in the IAR facilities to be rotated by raising it approximately 22 in. $\left(56 \mathrm{~cm}\right.$ ), rotating it $180^{\circ}$, and lowering it back into the facility. Steel shield plugs in the upper portion of the facility provide biological radiation shielding while this task is performed.

An instrumentation lead tube is attached to the lower rear portion of the facility. This lead tube contains all of the electrical heater extension leads and gas lines necessary for controlling the irradiation environment of the specimens. The lead tube extends above the pool water and provides a dry protective housing through which the leads extend to the control instrumentation as shown in Fig. 3.

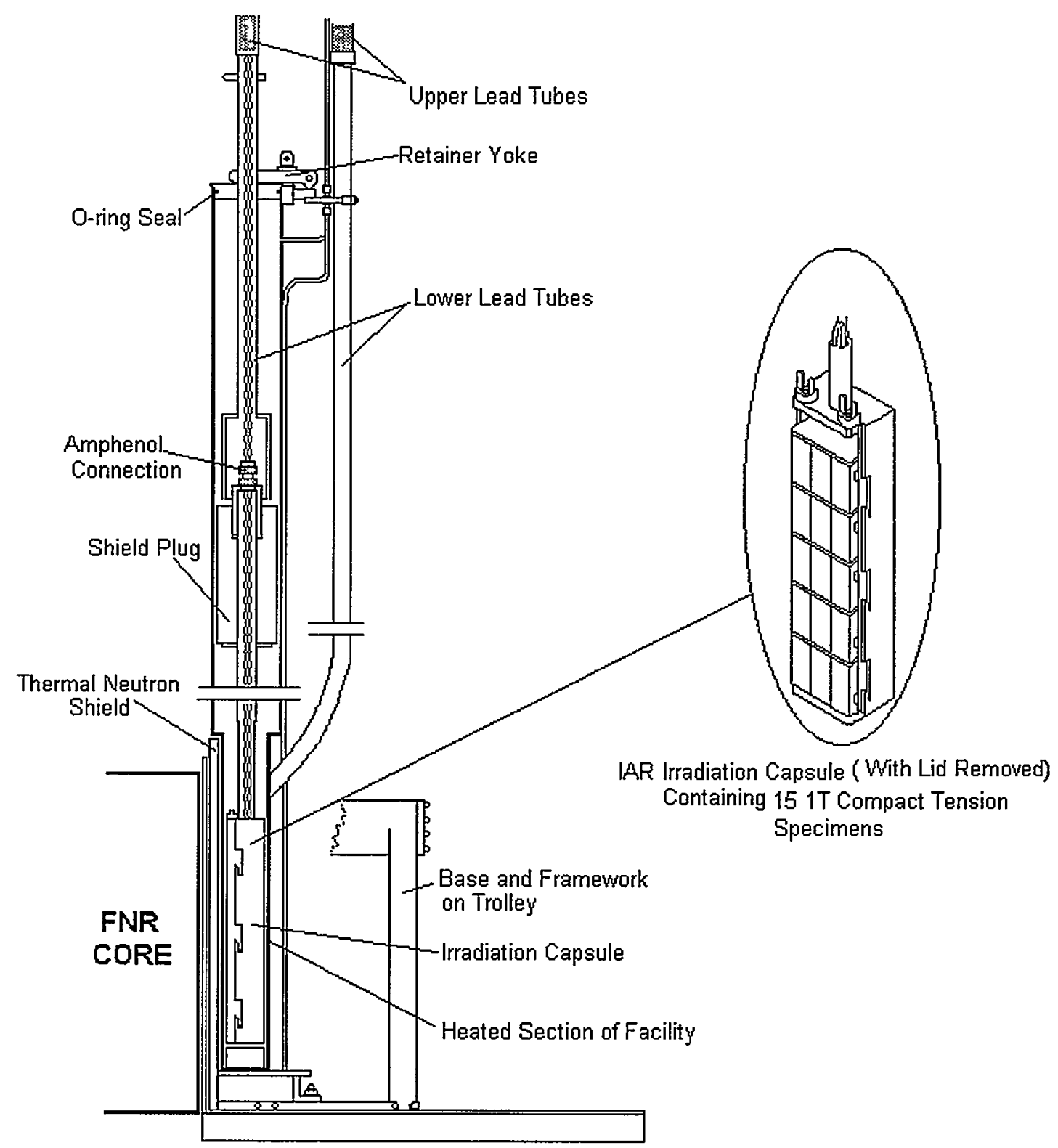

Figure 3. Schematic of HSSI-IAR irradiation capsule and facility at east face of FNR. 


\section{HSSI-IAR IRRADIATION CAPSULE}

The lower portion of the irradiation capsule (where the specimens are located) is essentially a box that is only slightly smaller than the inside of the lower (heated) portion of the facility. This allows the capsule to be transferred into and out of the facility but minimizes the gaps between the facility and the capsule to reduce thermal gradients within the facility. This box region of the capsule has interior cross-sectional dimensions of 3.03 by 2.40 in. $(77.0$ by $61.0 \mathrm{~mm}$ ), and because the capsule can be rotated, either of the long sides can be placed facing the reactor core. To facilitate loading of specimens, one of the long sides of the box serves as a lid and is removable.

The interior of the capsule is divided into five cells by the placement of shelf plates. Each cell is 2.52 in. $(64.0 \mathrm{~mm})$ high, which, when combined with the cross-sectional dimensions, permits loading three 1T compact-tension specimens (or their equivalent volume of other specimens and spacers) into each cell.

The capsule contains 26 Type-K thermocouples, which are 0.040 in. $(1.0 \mathrm{~mm})$ in diameter. Because one of the long sides of the box is removable and the other long side is only 0.045 in. $(1.14 \mathrm{~mm})$ thick, the thermocouples are imbedded in grooves in the two narrow side walls of the box and the shelf plates. To control and monitor specimen temperatures, the thermocouple measuring junctions are located in the sidewalls and at the front, middle, and back of the shelf plates. The capsule box assembly is shown in Figure 4 where the removable cover, shelf plates, and thermocouple measuring junction locations are identified.

A rigid lead tube extends from the top of the capsule box assembly to beyond the top of the facility. A flange on the upper portion of this lead tube contains an O-ring that seals the opening in the top of the irradiation facility when the capsule is inserted. The rigid lead tube is then attached to a flexible instrumentation lead hose that carries the thermocouple extension leads to the instruments that monitor and control the experiment.

\section{SPECIMEN EXCHANGES/ROTATION}

A very unique feature of these irradiation facilities is that the irradiation capsule is instrumented with thermocouples that are located within the complement of specimens in the irradiation capsule. However, it is still possible to transport the capsule assembly to the FNR hot cells for specimen transfers/rotations. This is accomplished by means of a multipin connector protected by a specially designed rigid capsule lead-tube joint that allows the lower $6 \mathrm{ft}(1.83 \mathrm{~m})$ of the irradiation capsule to be detached from the instrumentation. The lower half of the connector is fastened rigidly to the lower portion of the irradiation capsule. The upper half, with flexible extension leads, protrudes from the upper rigid portion of the instrumentation lead tube. When installed, the connection is surrounded by a split clamp and retainer can cover that provides a rigid and nonrotating joint between the upper and lower sections of lead tube connecting the irradiation capsule to the instrumentation facility.

By detaching the irradiation capsule from the instrumentation lead tube, the 6-ft-long $(1.83-\mathrm{m})$ lower portion of the irradiation capsule can be transferred to the FNR hot cells inside a specially designed lead-shielded cask. The cask was designed so that it can be loaded through the bottom 


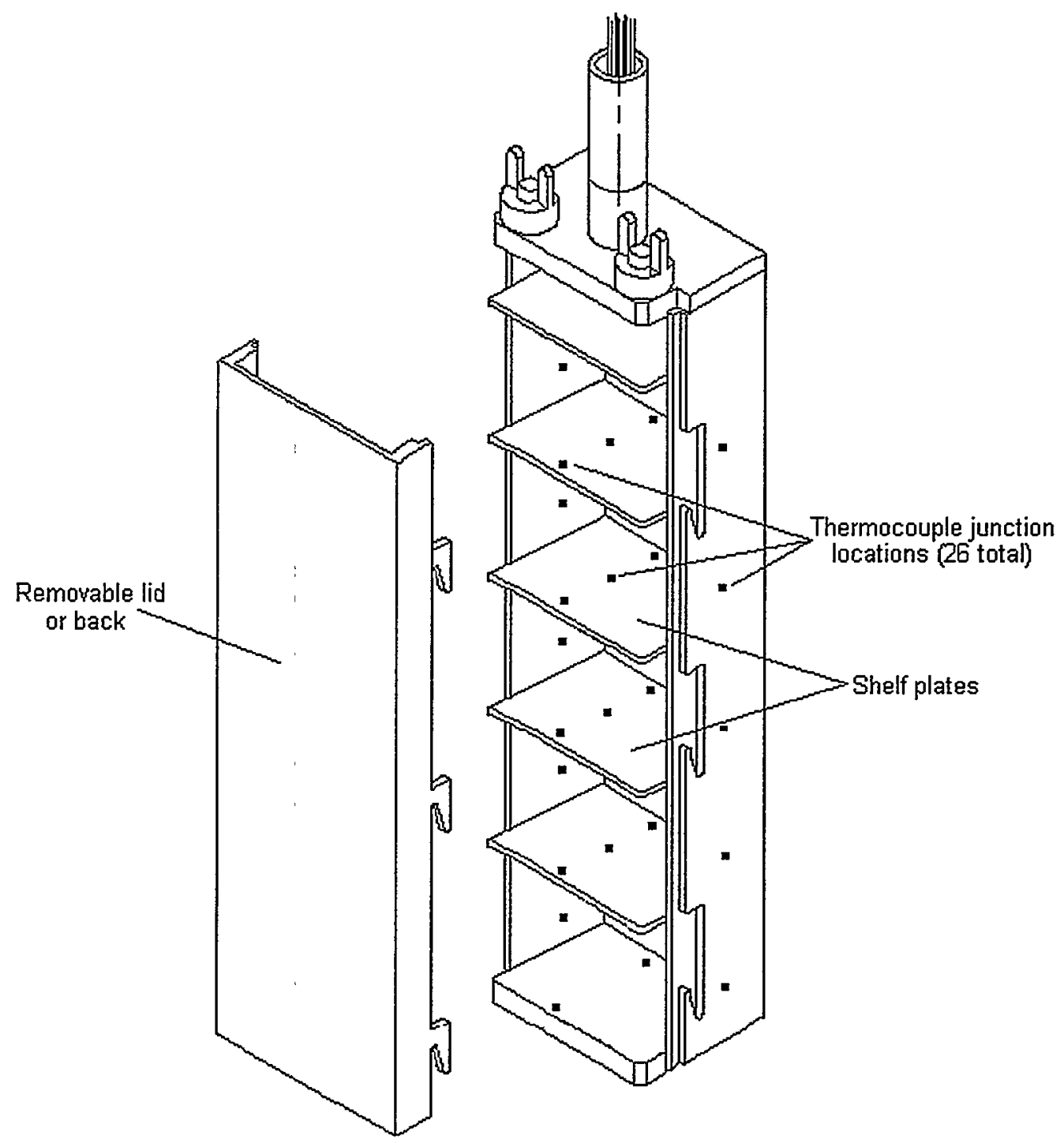

Figure 4. Shelf plate and thermocouple locations in the HSSI-IAR irradiation capsule.

while over the reactor pool and can be unloaded from a special opening in the side when in the hot cells. The capability of unloading the cask out the side in the hot cell was necessary because low headroom space in the cell would not allow the 6-ft-long section of the capsule to be unloaded out the top of the cask.

After removing the capsule from the cask in the hot cell, the lid can be removed from the irradiation capsule allowing the specimens to be removed, rotated, shuffled, or replaced. The removable lid has tapered ears on the sides that allow it to fit tightly against the specimens when installed but also allows lid removal by simply unlocking two latches and sliding it up and toward the top of the capsule as shown in Fig. 5. This feature of the capsule makes it possible to install new or preirradiated specimens into the capsule. This new and unique design requires no cutting or grinding operations to retrieve irradiated specimens. All capsule hardware is reusable, and 


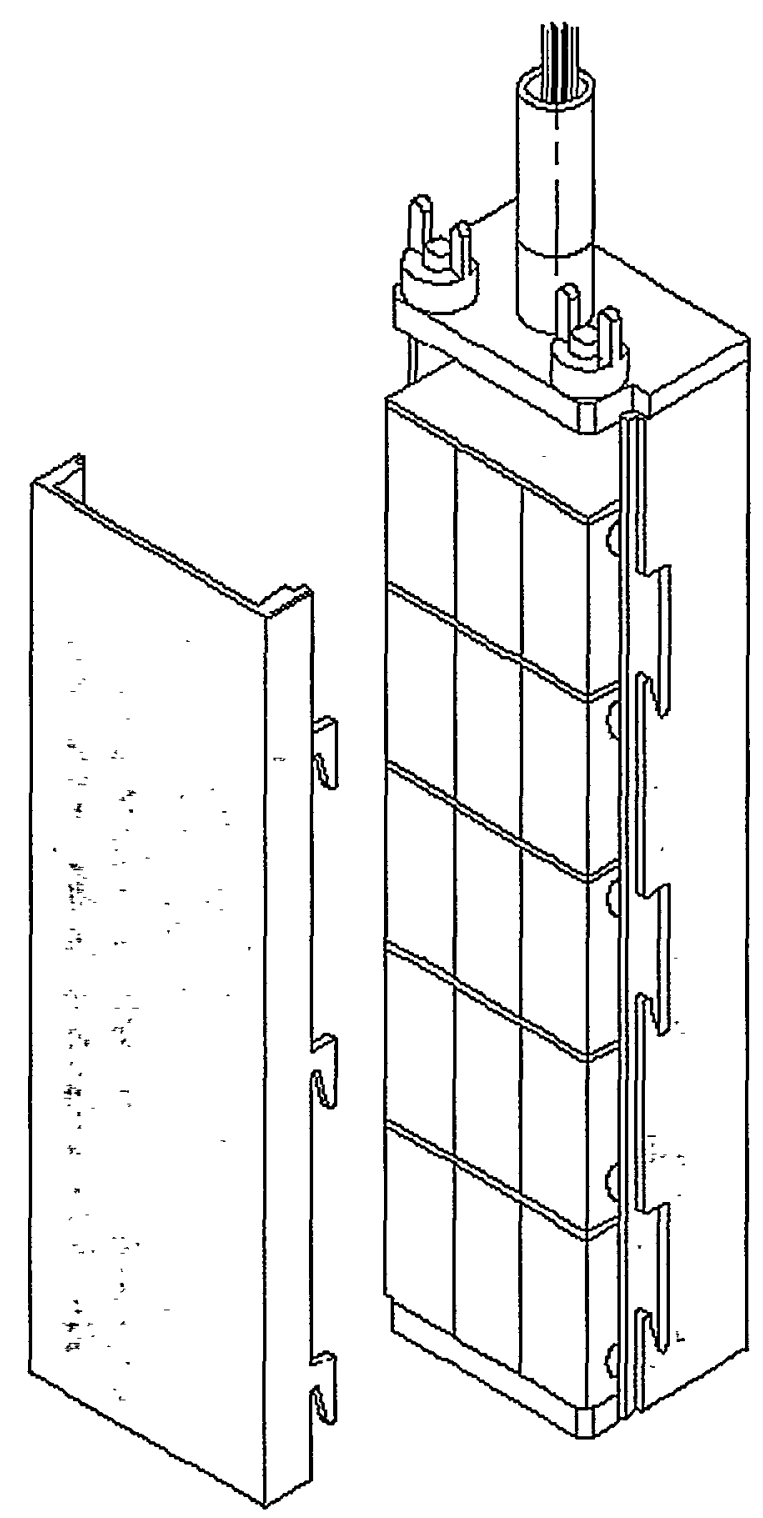

Figure 5. HSSI-IAR irradiation capsule and specimen container loaded with $151 \mathrm{~T}$ compact-tension specimens.

materials transported from site to site are limited to specimens only. Since specimens can be shipped from the irradiation site (FNR) to the testing site (ORNL) inside certified casks with over-packs, routine shipping and receiving procedures can be used.

\section{OPERATION OF THE HSSI-IAR FACILITIES}

To control the temperatures of specimens undergoing irradiation inside the IAR facilities, 12 permanently installed thermocouples in each IAR capsule were chosen to be the control thermocouples for the 12 heater zones in each IAR facility. Signals from the control thermocouples are sensed by heater controllers that increase or decrease the current applied to the electrical heaters inside the facility. This has proved to be a very successful method of temperature control. While it 
is possible to control the facilities anywhere between $200^{\circ} \mathrm{C}$ and $450^{\circ} \mathrm{C}$, the initial use of the facilities is to irradiate pressure vessel steels (which in power reactors operate at $288^{\circ} \mathrm{C}$ ), so the desired operating temperature is presently established to be $288 \pm 5^{\circ} \mathrm{C}$. During the temperature characterization tests, and with ongoing irradiations, it has been shown that all specimens inside the irradiation capsule can be maintained at temperatures within the range of $283^{\circ} \mathrm{C}$ to $293^{\circ} \mathrm{C}$. In fact, most of the thermocouples in both of the IAR facilities measure temperatures within $\pm 2^{\circ} \mathrm{C}$ of the desired $288^{\circ} \mathrm{C}$ irradiation temperature.

The FNR operates in 2-week increments (designated half-cycles) consisting of $10 \mathrm{~d}$ at power and $4 \mathrm{~d}$ shutdown. Startup of the reactor usually occurs on Tuesday, and shutdown occurs on the second Friday after startup. The 4-d period from shutdown on Friday until startup on the following Tuesday is used for reactor refueling and maintenance operations. During reactor shutdown periods the IAR facilities are retracted from the reactor face, and all electrical heaters are shut off.

Operation of the IAR facilities at temperature usually begins shortly after the reactor has been operating steadily at full power ( $2 \mathrm{MW}$ ) for at least $1 \mathrm{~h}$. During a typical startup of the irradiation facilities, electrical power is established to the heater controllers in the instrumentation facilities by touch controls on the HSSI computer screen. Using the same computer touch screen, the control system is then placed on "automatic," which applies a target value of $288^{\circ} \mathrm{C}$ to each of the controllers that supply electrical power to the heaters in the facility. As the facilities are heated to the target value (desired operating temperature), the heater controllers receive signals from the control thermocouples in the irradiation capsule and reduce the current supplied to the heaters in the facility. After the irradiation facilities are heated electrically to the desired temperature, FNR personnel crank the facilities against the east face of the core to continue irradiation of the specimens within the irradiation capsule. At the reactor face additional heating of the specimens, in the form of gamma heating from the FNR core, causes the control system to reduce the electrical power necessary to achieve desired temperatures. The desired operating temperature is maintained in this manner until the facility is shut down at the end of the reactor operating cycle.

\section{TEMPERATURE AND DOSIMETRY CHARACTERIZATION}

Temperature and dosimetry characterization were performed during the first two reactor halfcycles after installation. During these tests the irradiation capsules were loaded with 15 dummy $1 \mathrm{~T}$ compact-tension specimens that had been drilled for insertion of 9 flux gradient wires, 2 fission radiometric sets, and 3 sacrificial thermocouples. The gradient wires and fission radiometric sets were flux monitors to measure and map the flux in the different areas of the facilities.

Three sacrificial thermocouples were placed in each irradiation capsule in addition to the 26 thermocouples that are permanently installed in the irradiation capsule walls and shelf plates. The thermocouples were considered sacrificial because they were only used for temperature characterization and removed when the first metallurgical specimens were installed into the capsules. The three sacrificial thermocouples were inserted into holes drilled into three of the dummy specimens in each irradiation capsule. The dummy specimens containing the thermocouples were the middle specimen in the first, third, and fourth cell from the top of each capsule. The thermocouple hole location and depth made it possible to locate the three sacrificial thermocouple junctions in the center of the dummy specimens, allowing measurement of the temperature gradient across the 
specimens from the front to the back of the irradiation capsule as well as from the center of the middle specimens to the edge of the outer specimens. The metallurgical specimens to be tested would be damaged if they contained holes for insertion of thermocouples; therefore, the characterization tests were conducted with dummy specimens. Each group of metallurgical specimens to be irradiated, however, will contain flux monitors placed in the notches of the specimens to verify the fluence levels to which they are irradiated.

During the initial startup of the facilities (with the dummy $1 \mathrm{~T}$ specimens installed and with IAR-1 in the north position and IAR-2 in the south position), a series of temperature characterization tests were performed. In Fig. 6, the thermocouple temperatures for the gamma heating only (no electrical heat) test in the north facility (IAR-1) are presented. The 1T specimens are not shown in the figure so that thermocouple locations can be shown. Thermocouples 27,28 , and 29 were the sacrificial thermocouples inserted into the midplane of the center 1T specimen in the first, third,

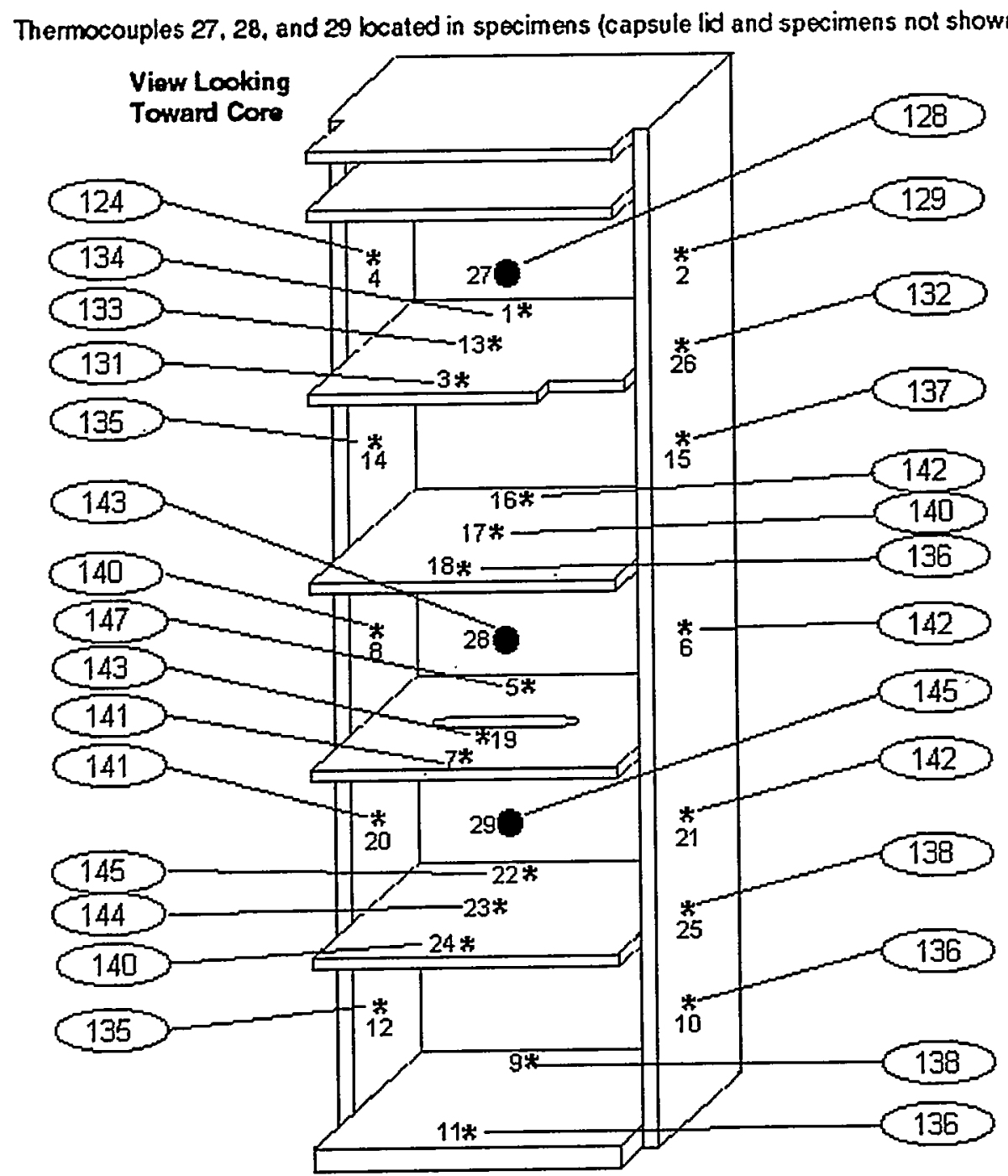

Figure 6. Thermocouple temperatures $\left({ }^{\circ} \mathrm{C}\right)$ for gamma heating only in the north facility (IAR-1). The reactor power is $2 \mathrm{MW}$ with $100 \%$ helium and no electrical heat. 
and fourth cell from the top of the capsule. Figure 7 illustrates the same information for the south facility (IAR-2). The front-to-back, top-to-bottom, and side-to-side temperature gradients induced by the gamma heating rate profiles can also be seen in these figures. The south facility has less total gamma heat because it is located on the southeast corner of the reactor and is in a lower gamma heating rate area than is the north IAR facility.

Subsequent to the gamma-heat-only tests and with the facilities still against the face of the reactor, electrical power was applied to the heaters, and the facilities were brought to desired operating temperatures. The resultant thermocouple temperatures for this test are shown in Figs. 8 and 9 for the north and south facilities, respectively. As can be seen in these figures, nearly all

Thermocauples 27.28 , and 29 bcated in specimens (capsule lid and specimens not shown)

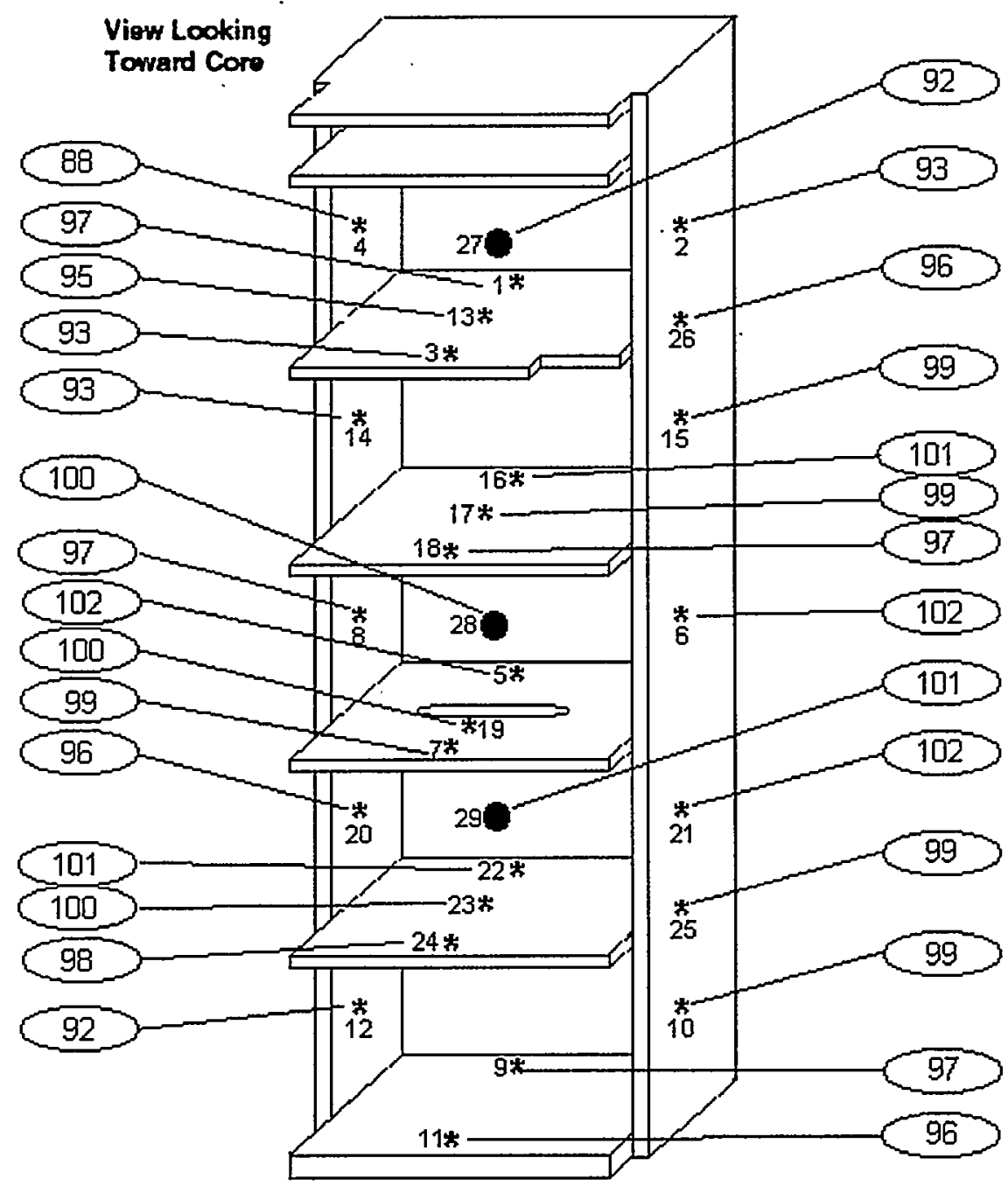

Figure 7. Thermocouple temperatures $\left({ }^{\circ} \mathrm{C}\right)$ for gamma heating only in the south facility (IAR-2). The reactor power is $2 \mathrm{MW}$ with $100 \%$ helium and no electrical heat. 
Thermocouples 27,28 , and 29 located in specimens (capsule lid and specimens not shown)

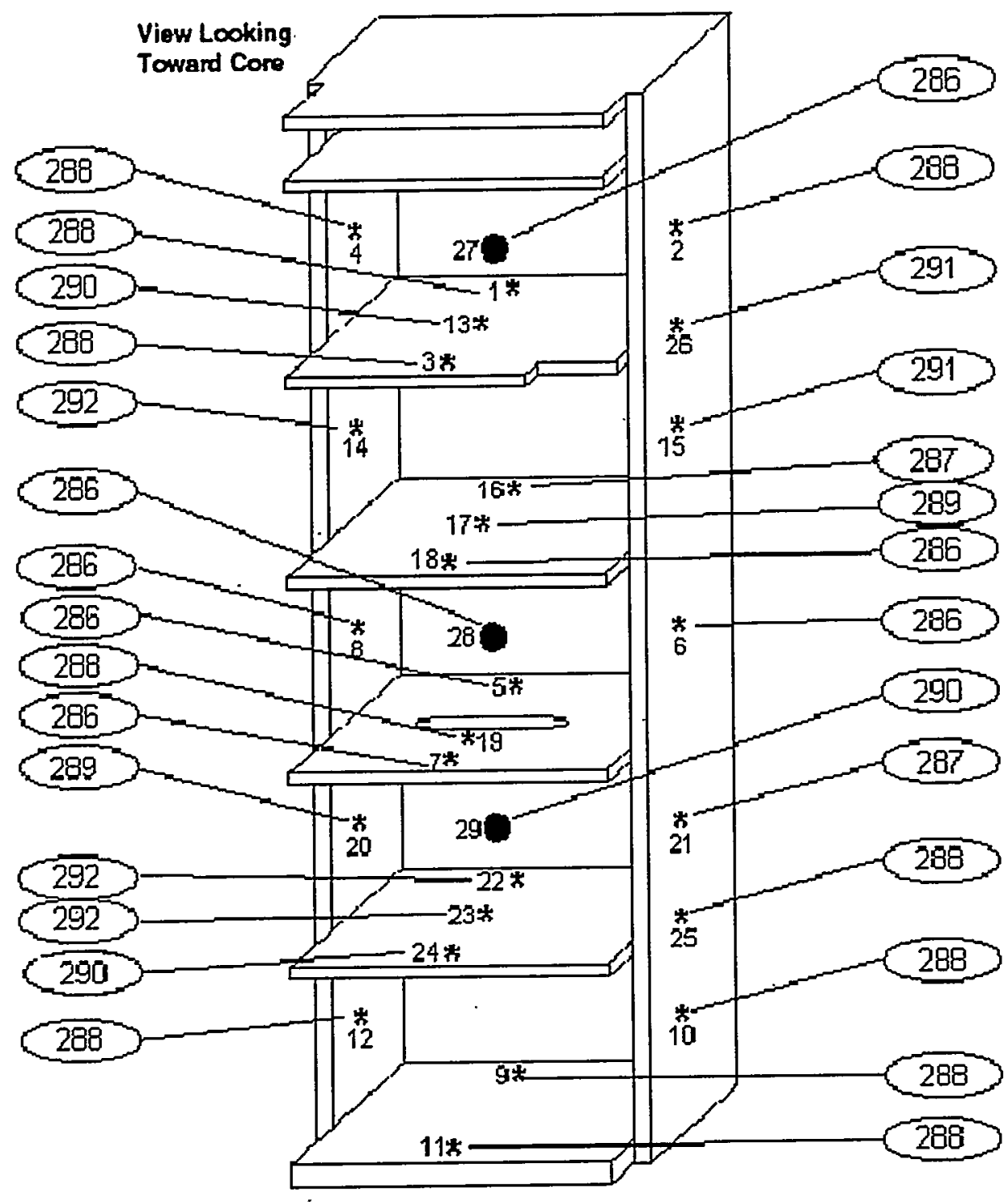

Figure 8. Thermocouple temperatures $\left({ }^{\circ} \mathrm{C}\right)$ with $3910 \mathrm{~W}$ electrical heating in the north facility (IAR-1). The reactor power is $2 \mathrm{MW}$ with $100 \%$ helium.

thermocouples are within $\pm 2^{\circ} \mathrm{C}$ of the desired operating temperature of $288^{\circ} \mathrm{C}$, including the sacrificial thermocouples $(27,28$, and 29$)$ imbedded in the dummy specimens. The facilities continued to operate at design temperature for the remainder of the half-cycle.

To begin the second half-cycle of characterization tests, the facilities were started up as they would be during routine operation; electrical power was applied to the heaters to bring the facilities to desired operating temperatures, and then they were moved against the face of the reactor. When the facilities are moved against the reactor face, the electrical heater controllers sense the additional gamma heat through the control thermocouple signals and reduce the electrical current 
Thermocouples 27.28. and 29 located in specimens (capsule lid and specimens not shown)

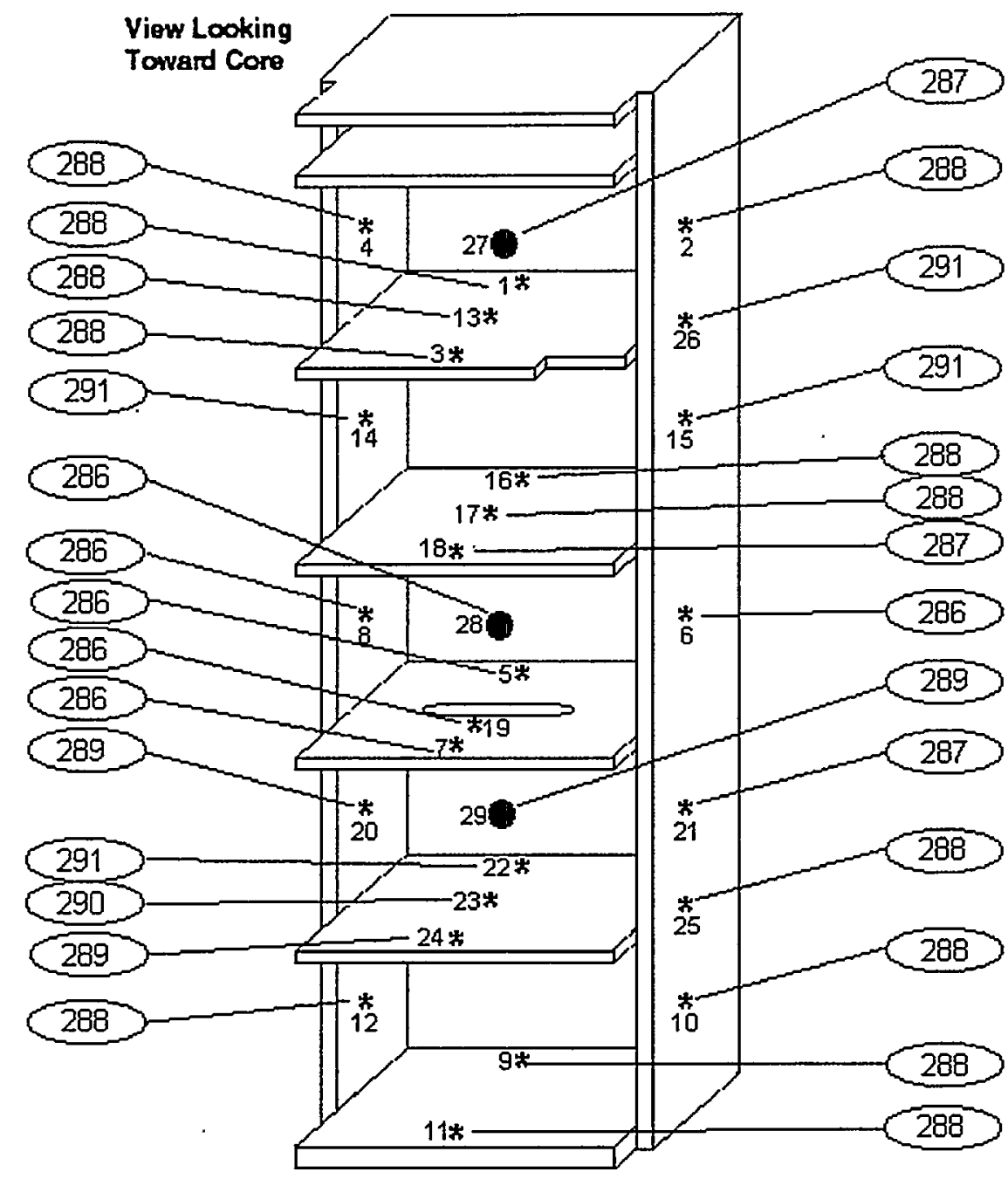

Figure 9. Thermocouple temperatures $\left({ }^{\circ} \mathrm{C}\right)$ with $5248 \mathrm{~W}$ electrical heating in the south facility (IAR-2 . The reactor power is $2 \mathrm{MW}$ with $100 \%$ helium.

supplied to the heaters to maintain the proper operating temperature. There are no measured temperature changes in the capsule as a result of moving against the face of the reactor. The total amount of power supplied by the electrical heaters is simply reduced by the heater controllers. Figure 10 shows the level of electrical heat input into the two IAR facilities while they are being moved against the reactor core. In Fig. 10 one can see that $\sim 5.7 \mathrm{~kW}$ of heat input was necessary in each facility to maintain the desired operating temperature in the withdrawn position. After insertion, the total electrical power input to the north facility (IAR-1) was reduced to $-3.6 \mathrm{~kW}$, and the total electrical power input to the south facility (IAR-2) was reduced to $\sim 4.8 \mathrm{~kW}$. The final total power after insertion may vary as much as 10-15\%, depending on the fuel loading for a given reactor cycle. The south facility always requires more electrical power to maintain desired 


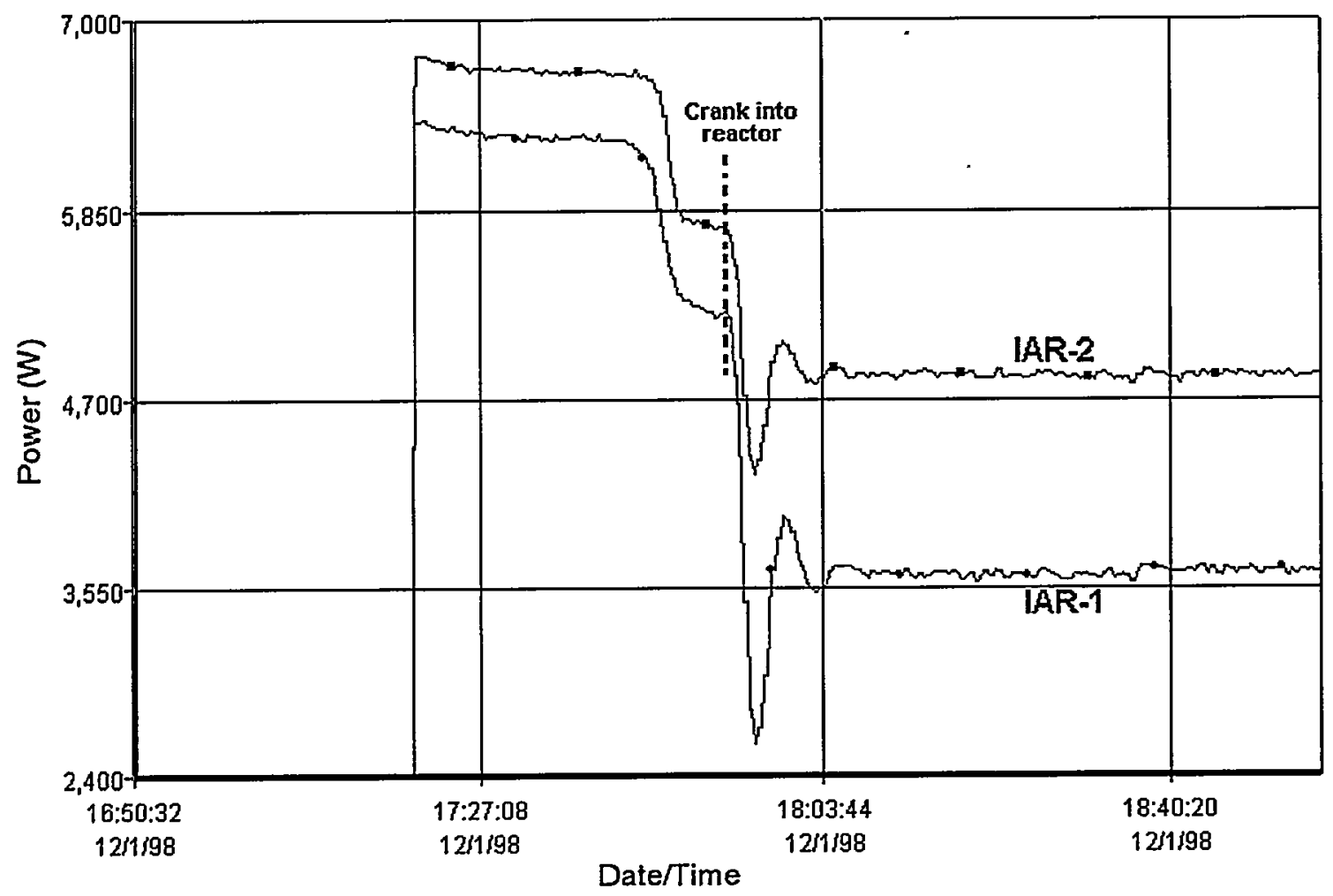

Figure 10. IAR-1 and IAR-2 electrical heater power input before and after cranking against reactor.

temperature because it is in a lower gamma heating area at the face of the core. The normal operating temperatures for the two IAR facilities are the same as those shown in Figs. 8 and 9.

After the HSSI-IAR facilities have been inserted against the reactor face for $\sim 30 \mathrm{~min}$, the outputs from the controllers become stable and tend to remain stable for the duration of the reactor cycle. The operating temperatures inside the irradiation capsules have remained stable since they were initially installed in November 1998. Figure 11 is a plot of temperature vs time for thermocouples 1-4 in the top cell of the IAR-1 facility. The time period covered in the plot is for a 10-d reactor half-cycle that ran from March 10-20, 1999. Figure 12 is an expanded view of the temperatures recorded for a short period of time taken from the plot in Fig. 11. Figure 12 indicates that for the 60-min period from $1 \mathrm{a}$ a.m. to $2 \mathrm{a}$.m. on March 15, 1999, none of the four thermocouples measured temperatures above $289^{\circ} \mathrm{C}$ nor below $287^{\circ} \mathrm{C}$. In fact, the variation in temperature during the 1-h period was about $0.6^{\circ} \mathrm{C}$. The temperature plot in Fig. 12 looks the same regardless of which portion of the plot it is taken from in Fig. 11. The HSSI-IAR facilities have exhibited excellent temperature control since they were installed. 


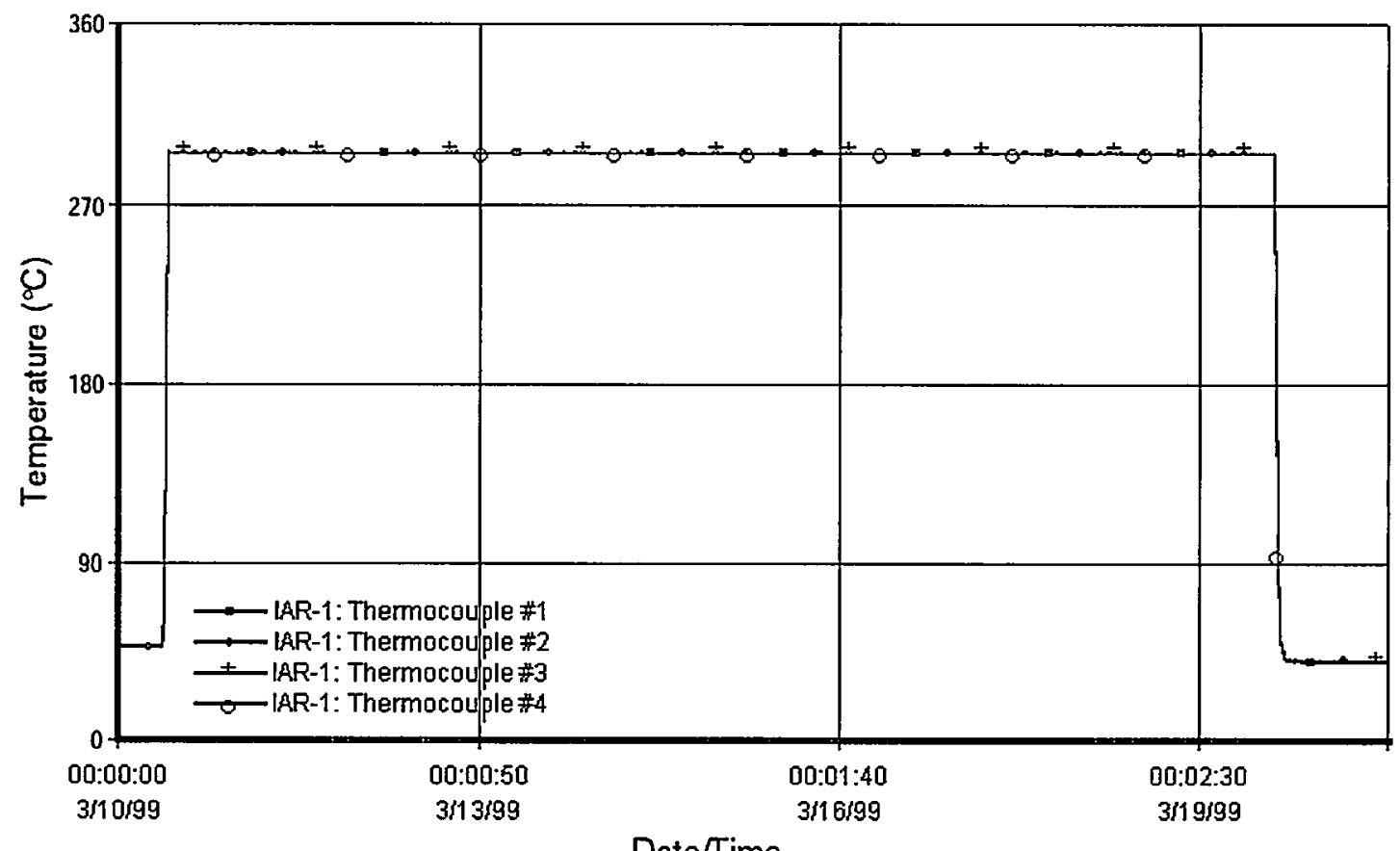

Figure 11. Temperature/time plot for thermocouples 1-4 in IAR-1 during complete reactor half-cycle.

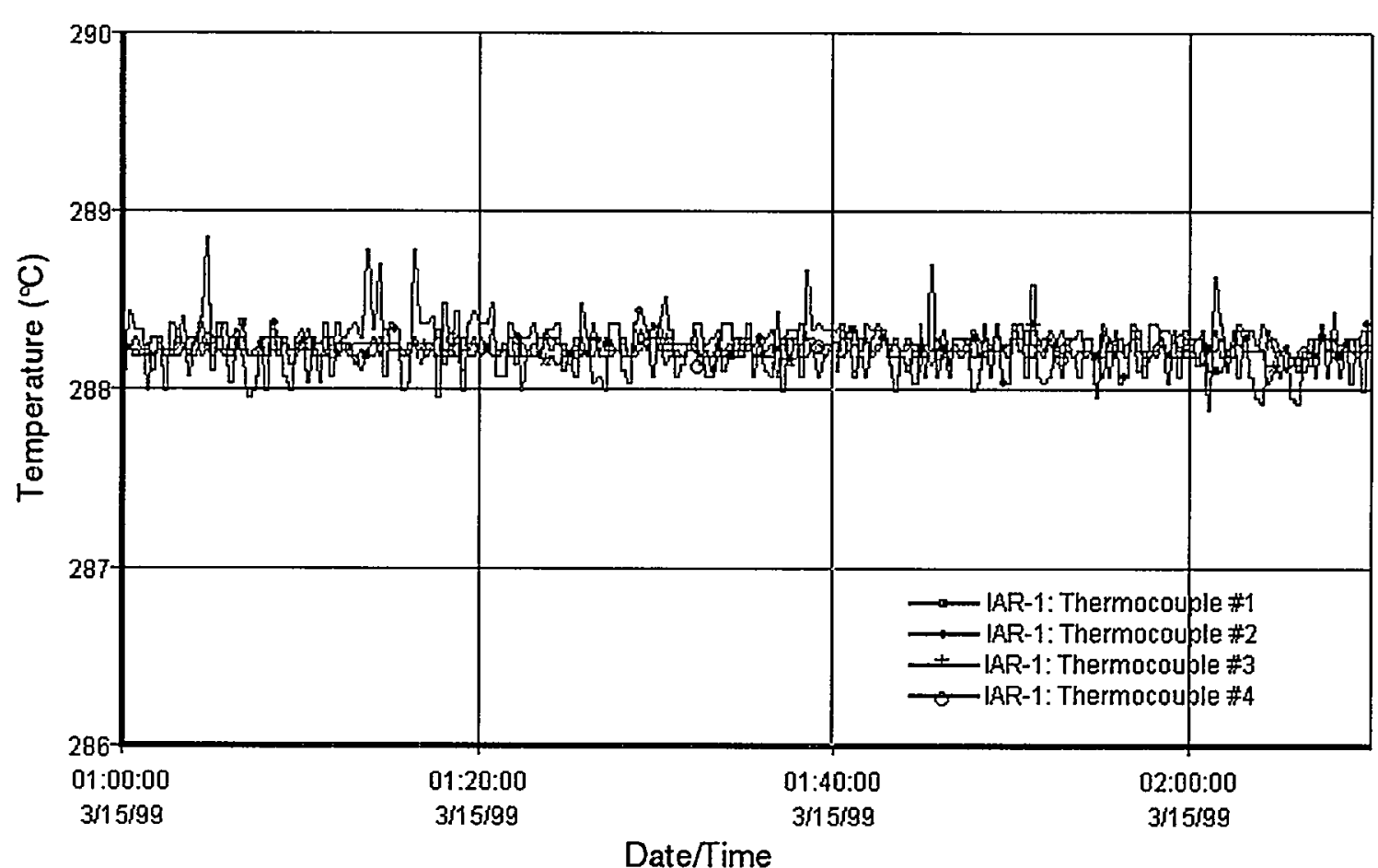

Figure 12. Temperature/time plot for thermocouples $1-4$ for short period of time indicating excellent temperature control. 


\section{CONCLUSION}

New irradiation facilities were designed and built to provide the NRC with irradiation facilities that are very flexible, dependable, and cost-effective. Their new and unique design requires no cutting or grinding operations to retrieve irradiated specimens, all capsule hardware is totally reusable, and materials transported from site to site are limited to specimens only.

The new HSSI/IAR irradiation facilities have been shown to provide excellent temperature control of metallurgical specimens inside the IAR capsules. The facilities and capsules are totally reusable. The irradiation capsules can be loaded with new or preirradiated specimens that can be inserted, removed, shuffled, and/or rotated at any point during the irradiation period. The irradiation capsules can be rotated inside the facilities, and if desired, they can be transferred from one facility to another to obtain different neutron flux. The IAR facilities can be used for heat treating metallurgical specimens when it is desirable to heat treat the entire compliment of specimens. If it is desirable to heat treat only a portion of the total specimen complement inside the capsule, the specimens can be transferred to a hot cell furnace for heat treatment while irradiation of other specimens continues.

\section{ACKNOWLEDGMENTS}

The authors would like to thank Don Raby, Phil Simpson, Bob Sitterson, Doug Sparks, and Eric Touchberry for their assistance in this project. This research was sponsored by the Office of Nuclear Regulatory Research, U.S. Nuclear Regulatory Commission under Interagency Agreement DOE 1886-N695-3W with the U.S. Department of Energy, under contract DE-AC0596OR22464 with Lockheed Martin Energy Research Corporation. 


\section{INTERNAL DISTRIBUTION}

1. C. A. Baldwin

2. B. R. Bass

3. R. A. Bradley

4. W. G. Craddick

5. D. F. Craig

6. E. C. Fox

7. H. W. Hayden, Jr.

8-13. D. W. Heatherly

14. M. T. Hurst

15. 'S. K. Iskander

16. K. E. Lenox

17. M. K. Miller

18. D. E. McCabe

19. J. G. Merkle

20. R. K. Nanstad
21. C. E. Pugh

22. A. L. Qualls

23. D. G. Raby

24. I. Remec

25-32. T. M. Rosseel

33. R. G. Sitterson

34. D. W. Sparks

35. R. E. Stoller

36-40. K. R. Thoms

41. R. L. Wallace

42. J. A. Wang

43. Central Research Library

44. Laboratory Records (RC)

45. Laboratory Records (OSTI)

\section{EXTERNAL DISTRIBUTION}

46. 2226 Cherokee Blvd., Knoxville, TN 37919-8343
I. I. Siman-Tov

47. ABB-COMBUSTION ENGINEERING, P.O. Box 500,. Mail Code 9483-1903, Windsor, CT 60695

S. T. Byrne

48. AEA TECHNOLOGY, Harwell, Thermal Reactor Services, Dideot, Oxfordshire, OXII, ORA, United Kingdom

C. A. English

49. ATI, Suite 160, 3860 Blackhawk Road, Danville, CA 94506

W. L. Server

50. BABCOCK AND WILCOX, B\&W R\&D Division, 1562 Beeson St., Alliance, OH 44601

W. A. Van Der Sluys 
51. BETTIS ATOMIC POWER LABORATORY, Westinghouse Electric Corp., P.O. Box 79, West Mifflin, PA 15122

M. G. Burke

52. CENTRAL INSTITUTE FOR NUCLEAR STUDIES, CEN/SCK, Reactor Physics Department, Boeretang 200, B-2400 Mol. Belgium

E. Van Walle

53-54. ELECTRIC POWER RESEARCH INSTITUTE, 1300 Harris Boulevard, Charlotte, NC 28262

R. G. Carter

S. T. Rosinski

55. FRAMATOME, Suite 218, 9040 Executive Park Drive, Knoxville, TN 37923

W. A. Pavinich

56-57. BATTELLE PACIFIC NORTHWEST LABORATORY, P.O. Box 999, Richland, WA 99352

F. A. Garner

M. L. Hamilton

58. NUCLEAR RESEARCH INSTITUTE, Division of Nuclear Materials, 25068 REZ, Czech Republic

M. Brumovshy

59. PAUL SCHERRER INSTITUTE, CH-5233 Villigen SPI, Switzerland

D. Katlhof

60. ROLLS-ROYCE AND ASSOCIATES LTD., P.O. Box 31, Raynesway, Derby DE24 8BJ, United Kingdom

T. J. Williams

61. STAATLICHE MATERIALPRUFUNGSANSTALT AND DER UNIVERSITAT STUTTGART, Pfaffenwaldring 32, 7 Stuttgart 80, Germany

J. Fohl 
62. U.S. DEPARTMENT OF ENERGY, Oak Ridge Operations Office, P.O. Box 2008, Oak Ridge, TN 37831-6269

Sherman Martin

63. U.S. DEPARTMENT OF ENERGY, Office of Nuclear Science and Technology, 19901 Germantown Rd., Germantown, MD 20874-1290
D. L. Harrison

64-69. U.S. NUCLEAR REGULATORY COMMISSION, Office of Nuclear Regulatory Research, MS T10-E10, Washington, D.C. 20555
J. W. Craig
C. J. Fairbanks
E. M. Hackett
M. T. Kirk
S. M. Malik
M. F. Mayfield

70-71. UNIVERSITY OF CALIFORNIA, Department of Chemical Engineering, Ward Memorial Drive, Santa Barbara, CA 93106
G. E. Lucas
G. R. Odette

72-74. UNIVERSITY OF MICHIGAN, Ford Nuclear Reactor, 2301 Bonisteel Blvd., Ann Arbor, MI 48109-2100
J. C. Lee
P. A. Simpson
E. Touchberry

75. UNIVERSITY OF MISSOURI-ROLLA, Department of Nuclear Engineering, Rolla, MO 65401
A. S. Kumar

76. WESTINGHOUSE ELECTRIC CORP., P.O. Box 355, Pittsburgh, PA 15320

W. Bamford

77. WESTINGHOUSE, 1310 Beulah Rd., Pittsburgh, PA 15325
R. G. Lott 